\title{
Study on the Reform Strategy of Education Management in Colleges and Universities Based on the Perspective of Innovation Education
}

\author{
Xiaohong Qin ${ }^{1, a^{*}}$ and Yonghong $\mathrm{Du}^{1, \mathrm{~b}}$ \\ School of Economics and Management, Xijing University, Xi'an 710023, China \\ aqinxiaohong12@sohu.com, b80477659@qq.com
}

Keywords: Innovation education; University education; Education management

\begin{abstract}
Education management is an important part of the management of colleges and universities, and it involves all aspects of the management, and plays an important role in the smooth development of teaching practice and the ability of students in Colleges and universities. In the reform and opening up today, the rapid development of China's economy needs more and more social talents. However, there are still a variety of problems in education management in Colleges and universities, which affects the growth and development of students. This paper studies and analyzes the reform of education management in Universities from the perspective of innovation education, and puts forward some effective strategies to solve the problems and drawbacks in the reform of higher education management.
\end{abstract}

\section{Introduction}

In the macro perspective, the analysis of college education management, specifically refers to under the government education departments leadership to plan and supervise the policy and the goal of the university education. For colleges and universities in terms of their own, it is by this scientific management to improve the ability of all aspects of the students, to make students to become social needs of the talent. So for the reform and innovation of college education management and wellsolving the problems existing in the education management, it has played a very important role in improving the teaching quality of colleges and universities, and it also has very important significance.

\section{The Realistic Problems of the Education Management in Colleges and Universities}

The Concept of Education Management in Colleges and Universities is Relatively Backward. University education management awareness is relatively weak, the management methods and means used in education management work is not reasonable, and too much emphasis on the role of teachers in the process of teaching, instead, ignoring the main body of student learning, cannot effectively stimulate the students' subjective initiative, so that it is difficult to improve the teaching quality of colleges and universities in our country at present.

Higher Education Management System is too Formal. Most colleges and universities have the related performance appraisal system to the teacher and the education management personnel, it is in order to raise the enthusiasm of the teachers and education administrators, to stimulate their learning ability in the work. However, the content of the University's performance appraisal is too single, only from a few Party in the face of teachers and education managers to do the contribution to the university, which causes many teachers and the education management personnel to the university education management system's dissatisfaction, resulting in the quality education reform work to actually implement to the real point.

The Comprehensive Quality of University Education Management is Relatively Low. Education management personnel as a very important part of the management of education management, the effectiveness of the management of college education directly depends on the quality. we can know in the actual survey, many of our higher education management personnel comprehensive quality is generally low, lack of basic professional ethics accomplishment, learning self consciousness is too low, it is difficult to modern advanced education management idea and 
technology applied to practical management work in, many of our higher education management personnel generally has a low comprehensive quality, lack of basic professional ethics accomplishment, and learning self consciousness is too low, who are difficult to apply modern advanced education management idea and technology to practical management work, which cause that the role and value of education management is difficult to reflect, thus affecting the ability of students in all aspects of training and improve.

The Management Effectiveness of the Education Management Personnel in Colleges and Universities is Low. On the management of colleges and universities in our country at present, the most obvious problem is that the efficiency of the management of higher education is low. Many manager's solving problem efficiency facing the problem is low, the responsibility of shirk each other often appear between the Department and the Department of state, which cause that University Management waste a lot of time and energy, it is difficult to effectively solve practical problems. Job classification is too complicated to reduce the efficiency of the management of colleges and universities. Management method is too single. Many colleges and universities did not form their effective management methods, but simply imitate other university management mode; a single management method often makes the university management work lose its own characteristics and core.

\section{Analysis on the Causes of the Problems in the Management of Colleges and Universities}

Lack of Scientific Guidance. College education management is one of the more unique aspects of the management, the lack of necessary guidance in theory is one of the reasons leading to the lack of education management in our country at present. In the previous work, the complexity of the management of the university education is seldom paid attention to, and the related staff in the university management thought the student work is simple and easy to deal with. In fact, most of the students are just 18 years old, lack of awareness of the community, so that the management of the school is very complex. There is a part of the university administrators are too dependent on the

[abstract] content, do not take into account the actual situation of the school itself, in the course of work out of practice, the lack of guidance in theory combined with practical scientific management. With the development and popularization of higher education, education management has become one of the indispensable links in higher education. Therefore, under the new education system, in the education request to management increasing day by day, the higher education management from the efficiency to the method is studied. The various problems in the management of higher education, China's higher education management launched innovative research, put forward the concept of scientific management, establish a more perfect management system, merit based selection. Make full use of the effective way of modern technology management; improve the current education management due to the lack of scientific guidance and the emergence of various problems.

Overly Burdensome Hierarchy Settings. Colleges and universities for institutional settings are often too cumbersome, but too much division of responsibility is not clear. For simple things often require layers of division labor, in such institutions will inevitably lead to lower efficiency. At the same time, various departments and between departments, but also easy to passing the buck "play ball" phenomenon, not only drag slow the progress of the work, also reduce the efficiency of work. Clearing dividing of labor, simplifying procedures, improve efficiency are the task of the current education management.

The Management System has not yet Formed a Standard. Today, the management work in Colleges and universities is still in the exploratory stage, most colleges and universities only were imitation of experience, not very good innovation, resulting in the with subjective imagination and experience imitation management mode is difficult to adapt to the actual situation. In the management system, most colleges and universities did not form their own management system; there is no clear regulations and requirements, resulting in a certain range of confusion and uncertainty. 
Worker Quality Gap is too Large. The uneven quality of workers is the main cause of the fault of the different links in the management of higher education in our country. Some workers have the professional quality of the higher education management staff, but there are also part of the workers in the management of colleges and universities itself does not have a corresponding quality of the "layman." Such staffing is an important reason for the problems in the process of the specific implementation of the management of college and university.

\section{Method of Innovating Education Management in Colleges and Universities}

Through the study of different degrees of problems in the management of University, we have carried out a more in-depth and innovative exploration of education management in Colleges and universities.

Establish a Scientific and Rational Management Concept. Different from the general enterprise management, the university education management is the special management science domain, the method also should be more targeted. Reasonable evaluation of students' Ideological and moral education, as well as the requirements of the students' teaching, understanding of the students' ideas make it better to accept and cooperate with the work. Higher education management workers itself should on their own has higher requirements, fully aware of the work of education and management playing important role in personnel training, personality training, establish a rigorous work ethic, for students to be responsible for the work of teaching. Pay attention to students' subject status in the process of education, build with students as the center of education management awareness, teachers in the teaching work constantly found their own inadequacies, through the study of relevant theoretical knowledge and enhance their understanding to improve. Teachers also need to starting from the student's interest, hobby and characteristics, reasonable use to stimulate students' interest in learning, to mobilize students' autonomous learning ability; construction of teachers and students of double subject teaching mode, improve the quality and efficiency of the education and management work in Colleges and universities; Setting fully reflected the role of education management, the level of the management of colleges and universities should be reasonable and scientific classification, establish scientific concept of college education and management, clear responsibility, ensure efficiency, makes the distribution more reasonable and efficient.

Improve the Clear and Efficient Management System. To establish a reasonable system of university education management in China's higher education management system, there are still many deficiencies, but there are a lot of more practical content, From the perspective of innovation education, should be based on the current education management system, combine with the needs of social development for the reform of college education management. First of all, the university should carry on the thorough research and the exploration to the educational management system of our country at present, to find out the problems and deficiencies in the education management system, and find out the problems, and formulate reasonable countermeasures for these problems; Secondly, learning the international or other colleges and universities advanced education management methods, and combine with the actual situation of their own schools; applying these modern concepts and methods to the education management of our school, we have to promote the development and progress of our school's education management work in the direction of standardization and modernization. In the end, the views and suggestions of the education management workers are summarized, and the reasonable contents are included in the process of the reform of the education management system. To change the traditional education management in Colleges and universities establishes the experience of a simple imitation of the phenomenon. The current university education management system to carry out a complete specification, the requirements of the work, content and evaluation criteria are strictly defined and divided. In view of the actual situation of the school develop the appropriate treatment methods. Therefore, in the process of education management work in Colleges and universities, to guide the scientific and organizational from the school to cope with the specific mode of management, introduced more standardized management regulations, make the management work of rule-based. Find a set of 
suitable for their own use of the educational management system, efficient management can be more efficient and orderly.

The Use of Meritocracy. At present, many colleges and universities, the choice of the way and the selection of the conditions are too arbitrary, many managers do not have the ability to scientifically manage the work of College education. Higher education management seat a more specific work, non professional personnel is very difficult to carry out scientific and reasonable management, the problems cannot be reasonably resolved, caused by different departments and between mutual buck passing caused by omission of education and management work in Colleges and universities. Therefore, in the selection process of the higher education management workers should put an end to the past, only to meet the basic demand of the idea, shall phase assessment, daily teaching work of reasonable arrangement and adjustment for the professional skills and ability to work. In strict accordance with the requirements of many aspects of the assessment, from the source of thought pay attention to the selection of professional management. Therefore, the education management staff recruitment, universities should be open to the public, fair recruitment, grasp the candidates in the comprehensive quality of the strict examination and approval; Establish a corresponding assessment system, regular assessment of the education management staff have been working, and give the appropriate rewards and punishments; To employ people with higher quality of education and management to carry out scientific training for the education management personnel in Colleges and universities, and to improve their management ability; Organize activities to promote the exchange of education management staff, enrich their work experience, and improve their ability to work. Build a more efficient management team.

Use of Modern Technology, Advanced Management. Traditional university education management is too dependent on labor, resulting in the work level cannot be improved, on the contrary, the redundancy makes the work process is too complicated, seriously affecting the efficiency of university education management. Thus, in today's rapid development of science and technology environment, the use of new technology and reference is necessary, and develop the entire university education management plat. On the daily teaching work, student learning activities, job evaluation and other online management, and change by the teachers, school leaders, students and the office of the administrative office of the final pass through the traditional way. In this way, the specific work process can be completed on the network platform, saving time, improve the efficiency, reduce personnel allocation, but also improve the education management system.

\section{Conclusion}

To sum up, the comprehensive management of university education in our country is still a variety of problems, we need to continue to explore study and solve the problem. Scientific and rational reform of university education management from the perspective of innovative education, should be from the people-oriented concept of college education management, combine with the actual situation of the school, respect for the development of students' interests and hobbies, establishing scientific and rational management system of higher education in Colleges and universities, the merit based personnel selection system, use modern technology, scientific management, improve the comprehensive quality of education management,

Simplified hierarchy, carry out scientific and rational guidance from these aspects, to set up scientific concept of education management in Colleges and universities, clearing responsibility, guaranteeing the efficiency and makes the work more efficient and reasonable, so as to improve the procedures of the University, improve the work efficiency, and fully demonstrated the role and value of education management in Colleges and universities, so as to achieve the purpose of improving the quality of teaching, promote students' health healthy growth and development. 


\section{References}

[1] Deng Caoxin, Xia Wei. Based on the high tech Zone Innovation of the University and the government cooperation governance network Capacity building research, JScience and technology progress and countermeasures, 2012 (22).

[2] Wang Zhanmei, Wang Shuangqiao. The existing problems of higher education and regional interactive development Policy Research (J). Education and careers, 2011 (15).

[3] Yang Aijun. Construction of the university teaching management system based on the idea of the people "J". Education and careers, 2011 (29).

[4] She Yuanfu, Liu Chao, Hu efficient. Three in one, four in one: Innovation of internal teaching in Colleges and Universities, Learning quality monitoring and evaluation of the long-term mechanism (J). Modern education management, 2011 (4).

[5] Peng Huanbin, political position, humanistic care, system construction, strengthening and Reform in the new era Into the ideological and political education work of College Teachers (J). Exploration, 2010 (1).

[6] Chen Hanbing. Problems and Countermeasures in the allocation of higher education resources in China J. Education xxplore.2012 (5).

[7] Yue Wu, Li Binbin. Structural layout of the resources allocation of higher education in China during the transition period Analysis (J). Journal of Northeast Normal University: Philosophy and Social Science Edition, 2011 (3).

[8] Bao Wei, Liu Yanhui. The factors influencing the allocation of higher education resources in China Linear model analysis (J). Research on educational development, 2011 (19)

[9] Ceng Yunyan. The examination reform of the ideological and political theory course in Colleges and universities from the perspective of innovation education [J]. Education and careers, 2013

[10]Lin Xiaodan. The implementation strategy of the cultivation of innovative talents in Colleges and universities from the perspective of Ideological and Political Education Study on [J]. Economic Research Journal, 2014 